\title{
Sistem Pendukung Keputusan Penentuan Siswa/i Berprestasi Menggunakan Metode Simple Additive Weighting (SAW) pada SMK Islam Assa'adatul Abadiyah
}

\author{
Mutiara Lailatul Ilmi ${ }^{1}$, Mutia Lailatul Ilmi ${ }^{2}$, Joko Dwi Mulyanto ${ }^{3}$
}

\begin{abstract}
Proses pemilihan siswa berprestasi membutuhkan ketelitian dan waktu yang lama, karena setiap data siswa harus dibandingkan dan nilai setiap siswa/i dihitung satu persatu sesuai dengan kriteria yang telah ditetapkan kemudian di urutkan dari siswa/i yang dimulai dari nilai, setelah itu dilakukan perangkingan sehingga ditemkan urutan siswa berprestasi dari ranking ke-1, ke-2, ke-3, dan seterusnya. Oleh kareana itu untuk menemukkan hasil sebuah keputusan dengan menghitung data alternatif, di perlukkan sebuah metode yang dapat membantu penyeleksian secara cepat, mudah dan meminimalisir terjadinya kesalahan dalam menentukan siswa berprestasi berdasarkan peringkat tersebut.dan oleh sebab itu penulis menerapkan sistem metode Simple Additive Weighting (SAW).
\end{abstract}

Kata Kunci: Sistem Pendukung Keputusan, Metode Simple Additive Weigthing $(\mathrm{SAW})$, Peringkat, Pemilihan Siswa Berprestasi.

Abstract-The process of selecting outstanding students requires thoroughness and a long time, because each student data must be compared and the value of each student is calculated one by one according to the criteria that have been set then sorted from the students / $i$ starting from the grades, after that is done warkingan so that the order of outstanding students from the 1st, 2 nd, $3 r d$, and so on. Therefore, to achieve the results of a decision by calculating alternative data, in the need of a method that can help the selection quickly, easily and minimize the occurrence of errors in determining students' achievements based on the ranking. and therefore the author applies a simple additive weighting (SAW) method system.

Keywords: Decision Support System, Simple Additive Weigthing (SAW)Method, Ranking, Selection of Outstanding Students.

\section{PENDAHULUAN}

\subsection{Latar Belakang}

Siswa/i berprestasi merupakan suatu kebangsaan bagi bangsa yang diharapkan untuk menjadi generasi yang dapat memajukan bangsa Indonesia. Untuk mendapatkan siswa/i berprestasi pihak sekolah harus memilih siswa/i yang memiliki kemampuan falam penguasaan pelajaran serta etika diri yang baik[1].

\footnotetext{
I, 2 Jurusan Sistem Informasi Universitas Nusa Mandiri, Jl. Tanjung Duren Timur Mandalika 4 No.2 RT.008/RW.006, email: yaya.ilmi19@gmail.com, mutialailatul89@gmail.com

${ }^{3} J u r u s a n$ Sistem Informasi Universitas Nusa Mandiri, Binangun Rt 02 Rw 06, Kec. Banyumas Kab Banyumas 53192, e-mail: joko.jdm@nusamandiri.ac.id
}

Setiap wali kelas akan mengumpulkan nilai dari setiap mata pelajaran yang mencakup ilmu pengetahuan, keterampilan, di nilai-nilai non akademik yang nantinya nilai tersebut akan diolah data nya dan setelah itu wali kelas akan menyusun laporan data nilai secara keseluruhan untuk mengetahui gambaran nilai yang di peroleh siswa/i di setiap mata pelajaran, kemudian membandingkan kembali nilai setiap sisawa/i dan untuk mendapatkan siapa siswa/i yang yang memperoleh nilai tertinggi sampai yang terendah. Setelah itu wali kelas barulah mengurutkan siswa/i dengan kriteria yang ditetapkan untuk dilakukan perangkingan atau peringkat sehingga ditemukan urutan siswa/i berprestasi[2]

Untuk menentukan siswa/i yang berprestasi pihak sekolah membutuhkan sistem pendukung keputusan yang dapat membantu dalam proses pemilihan siswa/i berprestasi sesuai ketentuan yang telah ditetapkan, dengan adanya sistem pendukung keputusan ini penyeleksian dilakukan secara cepat, mudah dan meminimalisir terjadinya kesalahan saat menentukan siswa/i berprestasi berdasarkan peringkat tersebut. Sistem pendukung keputusan (SPK) merupakan sistem yang interaktif membantu pengambilan suatu keputusan melalui penggunaan data dan model keputusan untuk memecahkan masalah[3].

Dari masalah latar yang telah di uraikan maka dari itu penulis oleh karena itu penulis mengambil penelitian yang berjudul "Sistem Pendukung Keputusan Penentuan Siswa/i Beprestasi Menggunakan Metode Simple Additive Weighting (SAW) pada SMK Islam Assa'adatul Abadiyah "

\subsection{Identifikasi Masalah}

Berdasarkan Identifikasi Masalah, penulis mengidentifikasikan beberapa masalah sebagai berikut:

1. Perhitungan untuk pengambilan keputusan siswa/i atau siswi berprestai masih dilakukan secara manual.

2. Sulitnya menentukkan siswa/i atau siswi berprestasi secara tepat dan akurat.

3. Belum adanya sistem dan metode untuk pengambilan keputusan siswa/i atau siswi yang berprestasi secara yang tepat dan akurat.

\subsection{Tujuan Penelitian}

Adapun tujuan pembuatan Sistem Penujang Keputusan dalam Penetuan Siswa/i Berprestasi dengan Metode Simple Additive Weighting (SAW) ini adalah :

a. Mempermudah penentuan dalam pengambilan keputusan siswa/i beprestasi pada SMK Islam Assa'adatul Abadiyah 
secara struktur dengan metode Simple Additive Weighting (SAW) .

b. Mempercepat proses kinerja guru dalam pengolahan data dan perhitungan agar hasil yang didapatkan tepat dan akurat.

c. Meminimalisir kesalahan saat melakukan perhitungan karena dilakukan secara terkomputerisasi.

\section{Metode Penelitian}

Konsep metode Simple Additive Weighting ( SAW ) adalah mencari penilaian terbobot dari rating kinerja pada setiap alternatif di setiap atribut dan membutuhkan proses dalam normalisasi matriks keputusan ( $\mathrm{X}$ ) ke suatu skala yang dapat membandingkan semua rating alternatif yang ada[4].

$$
\begin{aligned}
& r_{i j} \\
& =\left\{\begin{array}{l}
\frac{X_{i j}}{M a x X_{i j}} \rightarrow \text { jika } j \text { adalah atribut keuntungan } \\
\text { (Benefit) } \\
\text { MinX } X_{i j}
\end{array} \rightarrow\right. \text { jika j adalah atribut biaya (Cost) }
\end{aligned}
$$

Keterangan :

rij = nilai rating kriteria ternormalisasi

$\mathrm{Xij}=$ nilai atribut yang dimiliki pada setiap aspek sub kriteria

Max Xij = nilai terbesar setiap aspek sub kriteria

Min $\mathrm{Xij}=$ nilai terkecil setiap aspek sub kriteria

Benefit = jika nilai terbesar adalah sebuah nilai yang terbaik

Cost $=$ jika nilai terkecil adalah sebuah nilai yang terbaik

Hasil dari rating kinerja yang telah ternormalisasi (rij) dari alternatif Ai pada atribut $\mathrm{cj} ; \mathrm{I}=1,2, \ldots, \mathrm{m}$ dan $\mathrm{j}=1,2, \ldots, \mathrm{n}$. Dengan ini nilai preferensi untuk setiap alternatif (Vi) adalah sebagai berikut:

$$
V_{i}=\sum_{j=1}^{n} w_{j} r_{i j}
$$

\section{Keterangan :}

$\mathrm{Vi}=$ rating setiap alternatif

$\mathrm{Wj}=$ nilai bobot dari setiap kriteria

Rij = nilai rating kinerja yang ternormalisasi dari nilai

$\mathrm{Vi}$ yang lebih besar, menjelaskan bahwa alternatif $\mathrm{Ai}$ lebih terpilih.

\subsection{Tahapan Penelitian}

Untuk mendapatkan informasi yang dibutuhkan dalam tahapan penelitian ini, dibuatlah metedologi sebagai berikut :

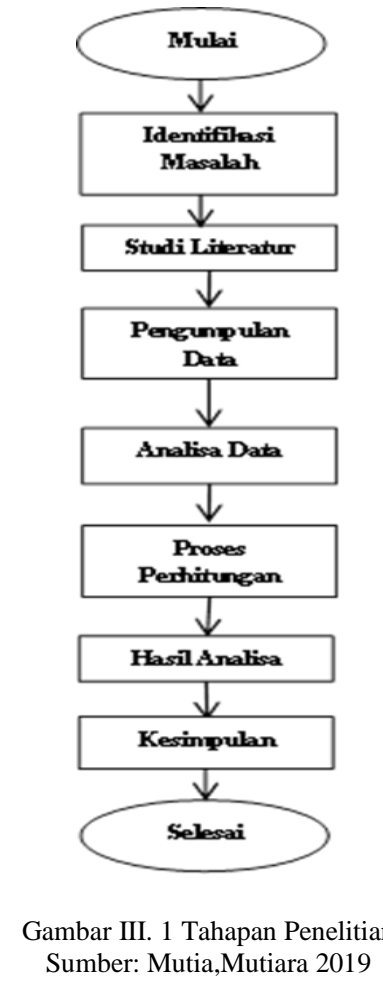

\subsection{Teknik Pengumpulan Data}

Metode yang digunakan penulis dalam mengumpulkan data atau informasi adalah sebagai berikut :

1. Observasi

Penulis mengumpulkan data-data yang diperlukan untuk membuat sistem penunjuang keputusan dengan metode Sample Additive Weighting (SAW) ini, dengan mengunjungi secara langsung SMK Islam Assa'adatul Abadiyah dan bertemu langsung dengan guru dan wali kelas untuk memperoleh informasi yang dibutuhkan.

2. Wawancara

Pada tahap wawancara, penulis melakukan tanya jawab dengan beberapa guru dan wali kelas terkait permasalahan dari objek penelitian untuk mendapatkan informasi yang akurat tentang proses pemilihan siswa berprestasi di SMK Islam Assa'adatul Abadiyah.

3. Studi Pustaka

Penulis memperoleh informasi yang bersal dari jurnaljurnal yang mempunyai masalah yang mirip untuk dijadikan sebagi acuan untuk mempelajari materi yang terkait dengan skripsi ini dan memperoleh informasi atau data yang diperlukan.

\subsection{Analisis Data}

Pada metode analisis data terdapat aspek sub kriteria dalam yang menjadi dasar dalam menentukkan peringkat siswa/i berprestasi, yaitu terdapat 4 sub kriteria[1]. :

1. Nilai Pengetahuan

- Nilai Pengetahuan terdiri dari :

1. Tugas

2. Ulangan Harian 


\section{UTS \\ 4. UAS}

2. Nilai Keterampilan

- Nilai Keterampilan terdiri dari :

1. Tugas portofolio (praktek)

3. Nilai absensi

- Nilai Absensi terdiri dari :

1. Sakit

2. Izin

3. Tanpa Keterangan

4. Sikap

- $\quad$ Nilai Sikap terdiri dari :

1. Sikap Spiritual

2. Sikap Sosial

\section{HASIL DAN PEMBAHASAN}

\subsection{Perhitungan Metode Simple Additive Weighting} (SAW)

Tahap Representasi masalah bertujuan untuk mengumpulkan semua data informasi siswa dan profile siswa dari lembaga pihak sekolah[1], dalam metode Simple Additive Weighting (SAW), terdapat langkah-langkah untuk menetukan perhitungan dalam memilih siswa terbaik, yaitu sebagai berikut[14] :

1. Menentukkan alternatif ( $A i)$

Pada tahap ini penulis memilih sampel siswa/i SMK Assa'adatul Abadiyah khususnya kelas XII.TKJ 3 tahun ajaran 2020/2021 dengan alternatif 5 siswa/i dengan nilai terbaik pada rapot semester 2, yaitu dapat pada lihat pada Tabel IV.1 di bawah ini :

Tabel IV. 1

Alternatif Siswa

\begin{tabular}{|c|c|c|c|c|c|c|}
\hline & Fatur & & & & & \\
\hline A4 & Dias & 82.3 & 81.9 & B & B & 4 \\
& Ad- \\
itya & & & & & \\
& $\begin{array}{c}\text { Sayhp } \\
\text { utra } \\
\text { G }\end{array}$ & & & & & \\
\hline A5 & $\begin{array}{c}\text { Rafid } \\
\text { Fildza } \\
\text { h } \\
\text { Dina }\end{array}$ & 82.6 & 81.4 & SB & SB & 5 \\
\hline
\end{tabular}

2. Menentukkan kriteria $\left(\mathrm{C}_{\mathrm{J}}\right)$ untuk menentukan siswa berprestasi, yang dapat dilihat pada Tabel IV.2 di bawah ini sebagai beikut :

Tabel IV. 2

Kriteria Siswa Berprestasi ( C )

\begin{tabular}{|l|l|l|}
\hline No & Kriteria & Aspek Sub Kriteria \\
\hline 1. & C1 & Nilai Pengetahuan \\
\hline 2. & C2 & Nilai Keterampilan \\
\hline 3. & C3 & Nilai Absensi \\
\hline 4. & C4 & Nilai Sikap \\
\hline
\end{tabular}

3. Menentukkan Bobot ( W ) pada kriteria, pada Tabel.IV.3 di bawah ini :

Tabel IV. 3

Bobot Nilai Kriteria

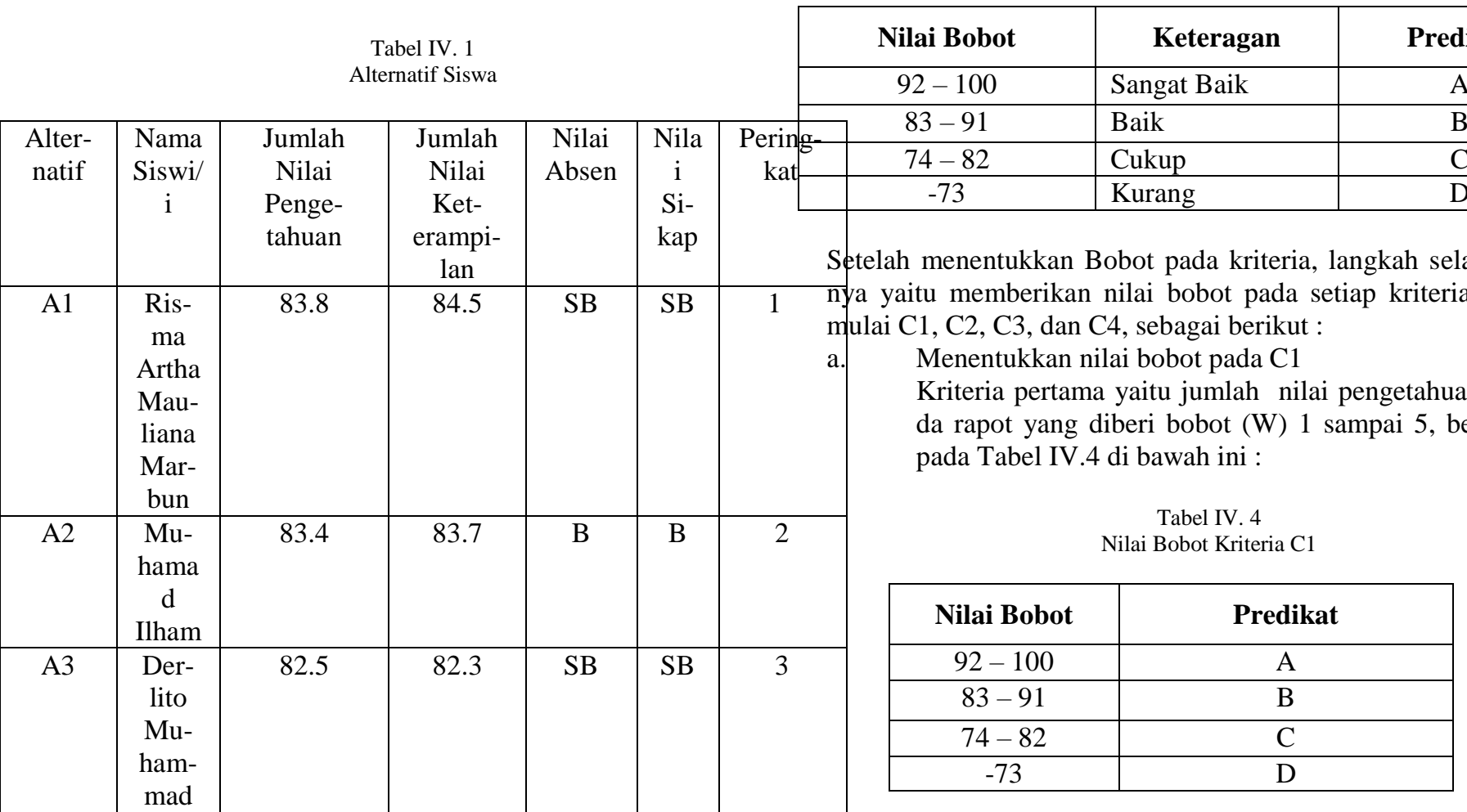


a. Menentukkan nilai bobot pada $\mathrm{C} 2$

Kriteria kedua yaitu jumlah nilai keterampilan pada rapot yang diberi bobot (W) 1 sampai 5, berikut pada Tabel IV.5 di bawah ini :

Tabel IV. 5

Nilai Bobot Kriteria C2

\begin{tabular}{|c|c|}
\hline Nilai Bobot & Predikat \\
\hline $92-100$ & $\mathrm{~A}$ \\
\hline $83-91$ & $\mathrm{~B}$ \\
\hline $74-82$ & $\mathrm{C}$ \\
\hline-73 & $\mathrm{D}$ \\
\hline
\end{tabular}

a. Menentukkan nilai bobot pada C3

Kriteria ketiga yaitu nilai absensi terkait pada rapot yang diberi bobot (W) 0 sampai 3, berikut pada Tabel IV.6 di bawah ini :

Tabel IV. 6

Nilai Bobot Kriteria C3

\begin{tabular}{|c|c|}
\hline Keterangan & Nilai Bobot \\
\hline SB & $92-100$ \\
\hline B & $83-91$ \\
\hline C & $74-82$ \\
\hline D & -73 \\
\hline
\end{tabular}

b. Menentukkan nilai bobot pada $\mathrm{C} 4$

Kriteria keempat yaitu jumlah nilai sikap yang terkait pada deskripsi sikap siswa/i yang menonjol pada Gambar IV.1 ,yang diberi bobot (W) 1 sampai 3, berikut pada Tabel IV.7 di bawah ini :

\begin{tabular}{|c|c|c|c|}
\hline NO & PILLHAN DESKRIPSI SIKAP SPIRTTUAL & NO & SIKAP SOSIAL \\
\hline 1 & berdoa sebelum dan sesudah melakukan kegatan & 1 & jujur \\
\hline 2 & menijankan badah sesuai dengan agamanya & 2 & disipin \\
\hline 3 & memberi salam pada sadt awal dan akhir kegatan & 3 & tanggung jawab \\
\hline 4 & bersyukur atas nikmat dan karuna Tuhan Yang Maha Esa & 4 & Santun \\
\hline 5 & mensyukuri kemampuan manusia dalam mengendalikan dini & 5 & percay din \\
\hline 6 & bersyuku ketika berhasi mengeriakan sesulutu & 6 & peduli \\
\hline 1 & berserah din (tawaka) kepada Tuhan setelean berikhtiar atau melakukan usoha & 1 & toleransi \\
\hline 8 & memelhara hubungan bäk dengan sesama umat & 8 & gotong royong \\
\hline 9 & bersyukur sebaga bangsa indonessia & 9 & nasionals \\
\hline 10 & menghormatio orang ain yang menijalankan badah sesua dengan agamanya & 10 & demokotis \\
\hline
\end{tabular}

Gambar IV. 1 Deskripsi Sikap Spiritual dan Sosial

Tabel IV. 7

Nilai Bobot Kriteria C4

\begin{tabular}{|c|c|}
\hline Keterangan & Nilai Bobot \\
\hline SB & $92-100$ \\
\hline B & $83-91$ \\
\hline C & $74-82$ \\
\hline D & -73 \\
\hline
\end{tabular}

4. Menentukan bobot (W) preferensi atau rating tingkat kepentingan dari setiap kriteria, berikut seperti pada Tabel IV.7 di bawa ini.

Tabel IV. 8

Rating Tingkat Kepentingan

\begin{tabular}{|l|c|c|c|c|}
\hline Kriteria & C1 & C2 & C3 & C4 \\
\hline Rating (\%) & 40 & 20 & 20 & 20 \\
\hline & 0,40 & 0,20 & 0,20 & 0,20 \\
\hline
\end{tabular}

5. Membuat tabel rating kecocokan setiap alternatif pada setiap kriteria

Tabel IV. 9

Rating Kecocokan Setiap Kriteria Alternatif

\begin{tabular}{|c|c|c|c|c|}
\hline Alternatif & C1 & C2 & C3 & C4 \\
\hline A1 & 83,8 & 84.5 & 98 & 98 \\
\hline A2 & 83.4 & 83.7 & 90 & 90 \\
\hline A3 & 82.5 & 82,3 & 98 & 98 \\
\hline A4 & 82,3 & 81,9 & 90 & 90 \\
\hline A5 & 82,6 & 81,4 & 98 & 98 \\
\hline
\end{tabular}

6. Tahap selanjutnya dari tabel rating kecocokan diatas didapat matrik keputusan, yaitu seperti pada Tabel IV.9 di bawah ini:

$$
X=\left(\begin{array}{llll}
83,8 & 84,5 & 98 & 98 \\
83,4 & 83,7 & 90 & 90 \\
82,5 & 82,3 & 98 & 98 \\
82,3 & 81,9 & 90 & 90 \\
82,6 & 81,4 & 98 & 98
\end{array}\right)
$$

7. Tahap selanjutnya yaitu normalisai matrik alternatif setiap alternatif, yaitu sebagai berikut :

$r_{i j=} \frac{x_{i j}}{\operatorname{Max} x_{i j}}$

1. Normalisasi matrik untuk A1

$$
\begin{aligned}
& \mathrm{r}_{11}=\frac{83,8}{\operatorname{Max}\{83,8 ; 83,4 ; 82,5 ; 82,3 ; 82,6\}}=\frac{83,8}{83,8}=1 \\
& \mathrm{r}_{12}=\frac{84,5}{\operatorname{Max}\{84,5 ; 83,7 ; 82,3 ; 81,9 ; 81,4\}}=\frac{84,5}{84,5}=1 \\
& \mathrm{r}_{13}=\frac{98}{\operatorname{Max}\{98 ; 90 ; 98 ; 90 ; 98\}}=\frac{98}{98}=1 \\
& \mathrm{r}_{14} \frac{98}{\operatorname{Max}\{98 ; 90 ; 98 ; 90 ; 98\}}=\frac{98}{98}=1
\end{aligned}
$$

2. Normalisasi matrik untuk A2

$$
\begin{aligned}
& \mathrm{r}_{21}=\frac{83,4}{\operatorname{Max}\{83,8 ; 83,4 ; 82,5 ; 82,3 ; 82,6\}}=\frac{83,4}{83,8}=0,995 \\
& \mathrm{r}_{22}=\frac{83,7}{\operatorname{Max}\{84,5 ; 83,7 ; 82,3 ; 81,9 ; 81,4\}}=\frac{83,7}{84,5}=0,990 \\
& \mathrm{r}_{23}=\frac{90}{\operatorname{Max}\{98 ; 90 ; 98 ; 90 ; 98\}}=\frac{90}{98}=0,918 \\
& \mathrm{r}_{24} \frac{90}{\operatorname{Max}\{98 ; 90 ; 98 ; 90 ; 98\}}=\frac{90}{98}=0,918
\end{aligned}
$$


3. Normalisasi matrik untuk A3

$$
\begin{aligned}
& \mathrm{r}_{31}=\frac{82,5}{\operatorname{Max}\{83,8 ; 83,4 ; 82,5 ; 82,3 ; 82,6\}}=\frac{82,5}{83,8}=0,984 \\
& \mathrm{r}_{32}=\frac{82,3}{\operatorname{Max}\{84,5 ; 83,7 ; 82,3 ; 81,9 ; 81,4\}}=\frac{82,3}{84,5}=0,973 \\
& \mathrm{r}_{33}=\frac{98}{\operatorname{Max}\{98 ; 90 ; 98 ; 90 ; 98\}}=\frac{98}{98}=1 \\
& \mathrm{r}_{34} \frac{98}{\operatorname{Max}\{98 ; 90 ; 98 ; 90 ; 98\}}=\frac{98}{98}=1
\end{aligned}
$$

4. Normalisasi matrik untuk alternatif A4

$$
\begin{aligned}
& \mathrm{r}_{41}=\frac{82,3}{\operatorname{Max}\{83,8 ; 83,4 ; 82,5 ; 82,3 ; 82,6\}}=\frac{82,3}{83,8}=0,982 \\
& \mathrm{r}_{42}=\frac{81,9}{\operatorname{Max}\{84,5 ; 83,7 ; 82,3 ; 81,9 ; 81,4\}}=\frac{81,9}{84,5}=0,969 \\
& \mathrm{r}_{43} \frac{90}{\operatorname{Max}\{98 ; 90 ; 98 ; 90 ; 98\}}=\frac{90}{98}=0,198 \\
& \mathrm{r}_{44} \frac{90}{\operatorname{Max}\{98 ; 90 ; 98 ; 90 ; 98\}}=\frac{90}{98}=0,198
\end{aligned}
$$

5. Normalisasi matrik untuk alternatif A5

$$
\begin{aligned}
& \mathrm{r}_{11}=\frac{82,6}{\operatorname{Max}\{83,8 ; 83,4 ; 82,5 ; 82,3 ; 82,6\}}=\frac{82,6}{83,8}=0,985 \\
& \mathrm{r}_{12}=\frac{81,4}{\operatorname{Max}\{84,5 ; 83,7 ; 82,3 ; 81,9 ; 81,4\}}=\frac{81,4}{84,5}=0,963 \\
& \mathrm{r}_{13}=\frac{98}{\operatorname{Max}\{98 ; 90 ; 98 ; 90 ; 98\}}=\frac{98}{98}=1 \\
& \mathrm{r}_{14} \frac{98}{\operatorname{Max}\{98 ; 90 ; 98 ; 90 ; 98\}}=\frac{98}{98}=1
\end{aligned}
$$

Tabel IV. 10

Normalisasi Matriks

\begin{tabular}{|c|c|c|c|c|}
\hline Alternatif & C1 & C2 & C3 & C4 \\
\hline A1 & 1 & 1 & 1 & 1 \\
\hline A2 & 0,995 & 0,990 & 0,918 & 0,918 \\
\hline A3 & 0,984 & 0,973 & 1 & 1 \\
\hline A4 & 0,982 & 0,969 & 0,918 & 0,918 \\
\hline A5 & 1 & 1 & 0,963 & 1 \\
\hline
\end{tabular}

Berikut ini adalah matriks normalisasi hasil dari perhitungan pada tabel diatas :

$$
R=\left(\begin{array}{cccc}
1 & 1 & 1 & 1 \\
0,995 & 0,990 & 0,918 & 0,918 \\
0,984 & 0,973 & 1 & 1 \\
0,982 & 0,969 & 0,918 & 0,918 \\
1 & 1 & 0,963 & 1
\end{array}\right)
$$

8. Menghitung nilai total integral

Hasil akhir nilai preferensi (Vi) yang diperoleh dari perkalian elemen baris matrik ternormalisasi $(\mathrm{R})$ dengan bobot preferensi (W). Nilai Vi yang nilainya lebih besar adalah alternatif yang terpilih, karena setiap nilai yang diberikan setiap alternatif pada setiap kriteria adalah nilai kecocokan dengan nilai yang terbesar adalah yang terbaik. Dalam hal ini 40 adalah bobot terbaik. Dengan ini, proses normalisasi matrik diambil nilai maksimum yang pembaginya. Maka nilai total integral untuk setiap alternatif adalah sebagai berikut :

$\mathrm{V}=W \times R$

Alternatif Optimal $=$ Maks V

1. Nilai total integral A1

$\mathrm{V}_{1}=(0,40) \times(1)+(0,20) \times(1)+(0,20) \times(1)+$

$(0,20) \times(1)=0,40+0,20+0,20+0,20=1 * 100$ $=100$

2. Nilai total integral $\mathrm{A} 2$

$\mathrm{V}_{2}=(0,40) \times(0,995)+(0,20) \times(0,990)+(0,20) \mathrm{x}$

$(0,918)+(0,20) \times(0,918)=0,398+0,198+0,1836$

$+0,1836=0,9632 * 100=96,32=96,3$

3. Nilai total integral A3

$\mathrm{V}_{3}=(0,40) \times(0,984)+(0,20) \times(0,973)+(0,20) \times$

$(1)+(0,20) \times(1)=0,3936+0,1946+0,20+0,20$

$=0,9882 * 100=98,82=98,8$

4. Nilai total integral A4

$\mathrm{V}_{4}=(0,40) \times(0,982)+(0,20) \times(0,969)+(0,20) \times$

$(0,918)+(0,20) \times(0,918)=0,393+0,194+0,1836$

$+0,1836=0,9542 * 100=95,42=95,4$

5. Nilai total integral A5

$\mathrm{V}_{5}(0,40) \times(0,985)+(0,20) \times(1)+(0,20) \times(0,963)$

$+(0,20) \times(1)=0,394+0,20+0,193+0,20=$

$0,987 * 100=98,7$

Hasil dari perhitungan nilai total integral diatas adalah :

Tabel IV. 11

Hasil Nilai Total Integral

\begin{tabular}{|c|c|c|}
\hline Alternatif & Nama Siswi/i & Hasil \\
\hline A1 & $\begin{array}{c}\text { Risma Artha Mauliana } \\
\text { Marbun }\end{array}$ & 100 \\
\hline A2 & Muhamad Ilham & 96,3 \\
\hline A3 & Derlito Muhammad Fatur & 98,8 \\
\hline A4 & Dias Aditya Sayhputra G & 95,4 \\
\hline A5 & Rafid Fildzah Dina & 98,7 \\
\hline
\end{tabular}

Tabel IV. 12

Rating Keputusan 
VOL. VII NO. 2 AGUSTUS 2021

\begin{tabular}{|l|l|l|l|l|}
\hline & Siswi/i & Integral & & \\
\hline A1 & $\begin{array}{l}\text { Risma Ar- } \\
\text { tha Mauli- } \\
\text { ana Marbun }\end{array}$ & 100 & A & 1 \\
\hline A2 & $\begin{array}{l}\text { Muhamad } \\
\text { Ilham }\end{array}$ & 96,3 & A & 4 \\
\hline A3 & $\begin{array}{l}\text { Derlito } \\
\text { Muhammad } \\
\text { Fatur }\end{array}$ & 98,8 & A & 2 \\
\hline A4 & $\begin{array}{l}\text { Dias Aditya } \\
\text { Sayhputra } \\
\text { G }\end{array}$ & 95,4 & A & 3 \\
\hline A5 & $\begin{array}{l}\text { Rafid } \\
\text { Fildzah } \\
\text { Dina }\end{array}$ & 98,7 & A & 5 \\
\hline
\end{tabular}

Berdasarkan tabel rating kepentingan, nilai terbesar yang terdapat pada tabel di atas yaitu alternatif A2, dan $\mathrm{Mu}-$ hamad Ilham yang memperoleh nilai terbaik 99 dengan predikat A,yaitu sangat baik.

\subsubsection{Perancangan Use Case}

Pada perancangan use case diatas terdapat 2 aktor yaitu user dan admin

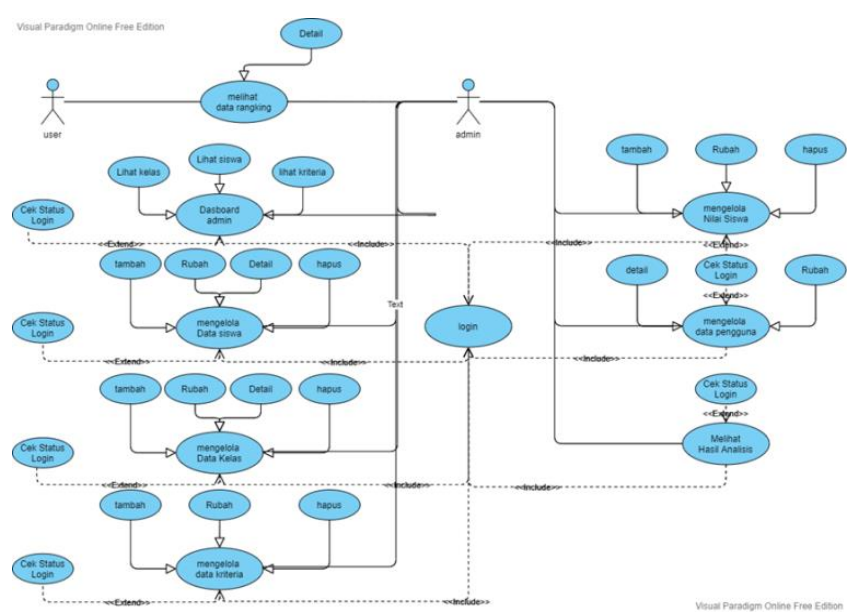

Gambar IV. 2 Use Case Diagram

1. Admin

Admin adalah orang yang mengelola sistem, yaitu mengakses login, logout, mengelola data master yang meliputi dat semua siswa, data siswa per kelas, data kelas, data nilai siswa, data pengguna, data hasil analisa.

2. User

User adalah aktor yang memakai tau pengguna sistem, yaitu dapat melihat situs web namun tidak bisa mengakses data pada sistem admin.

4.1.1.2 Perancangan Database

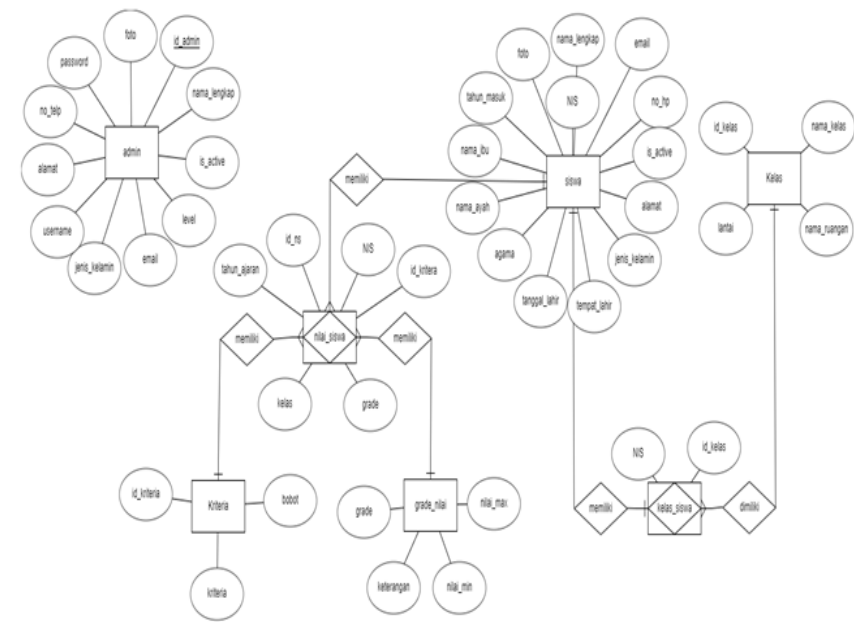

Gambar IV. 3 ERD Database

4.1.1.3 Tampilan Website

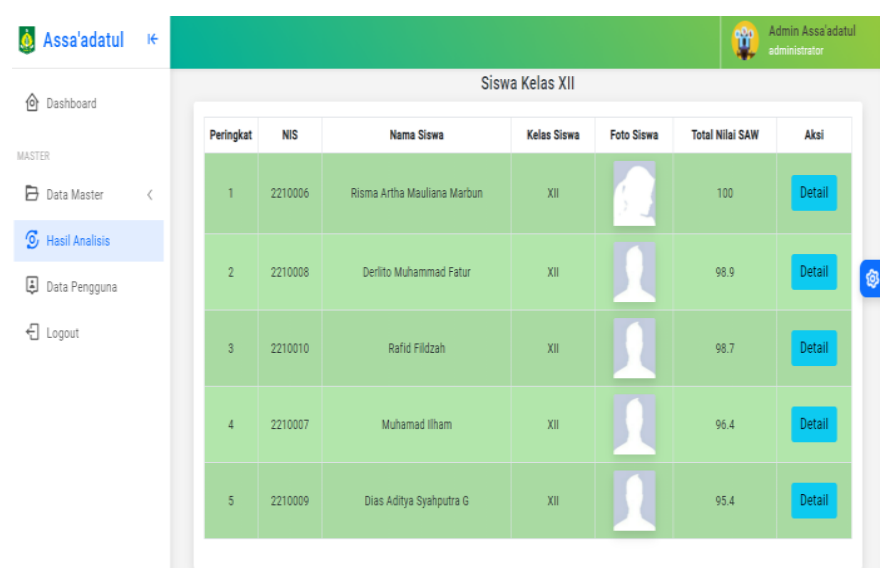

Gambar IV. 4 Tampilan User

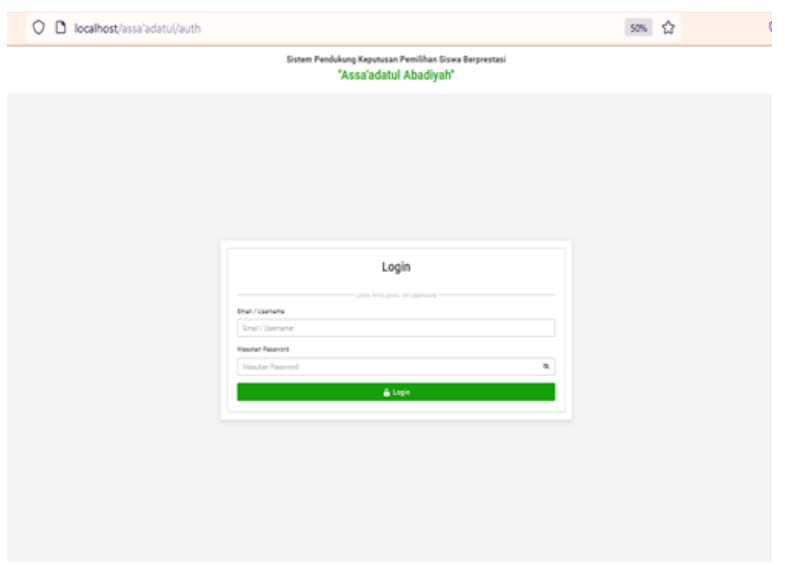

Gambar IV. 5 Tampilan Login Admin 


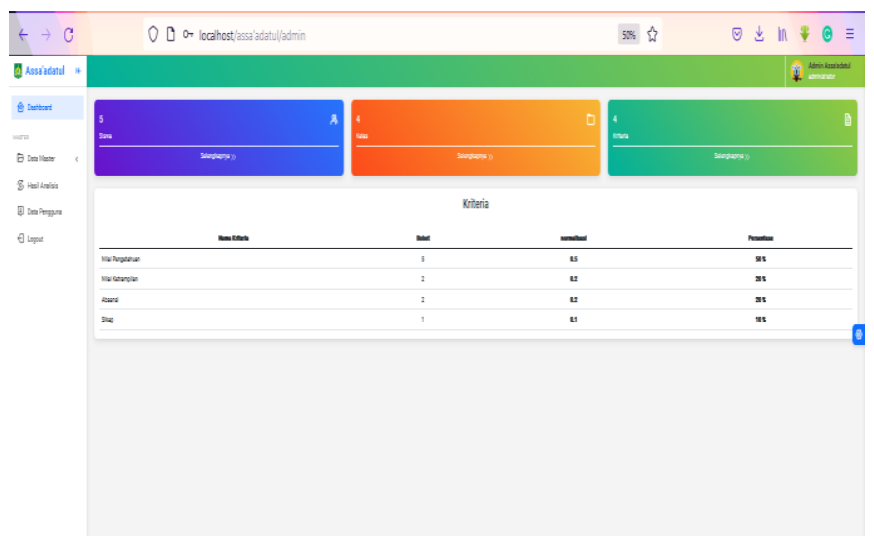

Gambar IV. 6 Tampilan Halaman Admin

\subsection{Potensi Hasil}

Dari perhitungan peringkat di atas dar perhitungan siswa pada SMK Assa'adatul Abadiyah menggunakan metode Simple Additive Weighting (SAW) didapatkan namanama siswa sebagai berikut:

Tabel IV. 13

Potensi Hasil

\begin{tabular}{|c|c|c|c|c|}
\hline Alternatif & $\begin{array}{c}\text { Nama } \\
\text { Siswi/i }\end{array}$ & $\begin{array}{c}\text { Nilai } \\
\text { Total } \\
\text { Integral }\end{array}$ & Predikat & Peringkat \\
\hline A1 & $\begin{array}{c}\text { Risma Ar- } \\
\text { tha Mauli- } \\
\text { ana Marbun }\end{array}$ & 100 & $\mathrm{~A}$ & 1 \\
\hline A2 & $\begin{array}{c}\text { Muhamad } \\
\text { Ilham }\end{array}$ & 96,3 & $\mathrm{~A}$ & 4 \\
\hline A3 & $\begin{array}{c}\text { Derlito } \\
\text { Muhammad } \\
\text { Fatur }\end{array}$ & 98,8 & $\mathrm{~A}$ & 2 \\
\hline A4 & $\begin{array}{c}\text { Dias Aditya } \\
\text { Sayhputra } \\
\text { G }\end{array}$ & 95,4 & $\mathrm{~A}$ & 3 \\
\hline A5 & $\begin{array}{c}\text { Rafid } \\
\text { Fildzah } \\
\text { Dina }\end{array}$ & 98,7 & $\mathrm{~A}$ & 5 \\
\hline
\end{tabular}

Dengan adanya metode Simple Additive Weighting (SAW) dapat membantu kegiatan guru wali kelas dalam menentukkan siswa berprestasi.

\section{KESIMPULAN}

\subsection{Kesimpulan}

Berdasarkan analisis dengan metode SAW pada kasus pemilihan siswa ber-prestasi pada SMK Islam Assa'adatul Abadiyah, maka dapat disimpulkan se-bagai berikut:

a. Perhitungan analisis data pada setiap alternatif dan kriteria yang ada dengan metode SAW dapat menghasilkan peringkat siswa berprestasi. b. Dari perhitungan peringkat pada penelitian ini pada SMK Assa'adatul Abadiyah menggunakan metode Simple Additive Weighting (SAW) didapatkan nama-nama siswa yang mendapat nilai tertinggi yaitu yaitu alternatif A2, Muhamad Ilham yang memperoleh nnilai terbaik dengan predikat A dengan nilai total integral 99.

\subsection{Saran}

Saran yang dapat di berikan oleh penulis mengenai penelitian ini adalah :

a. Selain menggunakan metode SAW, banyak metode yang mungkin dapat menghitung siswa berprestasi.

b. Diharapkan dengan adanya sistem perhitungan ini dapat mempermudah guru walikelas dalam menentukkan siswa brprestai dan dikembangkan lagi menjadi sistem yang lebih baik.

\section{UCAPAN TERIMA KASIH}

Terima kasih saya ucapkan kepada seluruh tim jurnal JTI dan seluruh tim yang terkait dalam menerbitkan tulisan paper skripsi yang telah saya buat, dengan adanya jurnal ini sangat membantu khususnya saya dalam menyesuaikan tata tulisan paper skripsi yang telah saya buat.Sekali lagi saya ucapkan terima kasih.

\section{REFERENSI}

Y. Apriyani, M. Hidayat, and D. Sudarsono, "Penentuan Siswa Berprestasi Menggunakan Metode SAW pada SMA Negeri 9 Tasikmalaya," (Indonesian J. Comput. Inf. Technol., vol. 4, no. 1, pp. 27-35, 2019, [Online]. Available: https://ejournal.bsi.ac.id/ejurnal/index.php/ijcit/article/view/4549. R. L. Pradana, D. Purwanti, and A. Arfriandi, "Sistem Pendukung Keputusan Pemilihan Siswa Berprestasi Berbasis Website dengan Metode Simple Additive Weighting," J. Sist. Inf. Bisnis, vol. 8, no. 1, p. 34, 2018, doi: 10.21456/vol8iss1pp34-41.

J. P. S. Adi and W. Windarto, "Pendukung Keputusan Pemilihan Siswa Terbaik Pada Sma Cenderawasih 2 Dengan Menggunakan Metode Simple Additive Weighting Berbasis Web," Sebatik, vol. 23, no. 2, pp. 534-540, 2019, doi: 10.46984/sebatik.v23i2.826.

S. Suwarno and M. R. Muhtarom, "Sistem Pendukung Keputusan Penentuan Penilaian Siswa Dengan Metode Saw (Simple Additive Weighting)," ... Based Inf. Syst. J., vol. 01, pp. 23-36, 2021. 


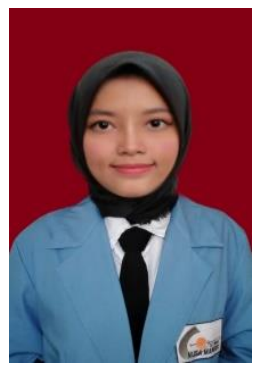

Mutiara Lailatul Ilmi, A.Md.Kom. Jakarta 01 November 1998 dan tanggal lahir. Mahasiswi Universitas Nusa Mandiri Jakarta yang merupakan lulusan Ahli Madya Komputer dari Program Studi Sistem Informasi Universitas Bina Sarana Informatika Jakarta.

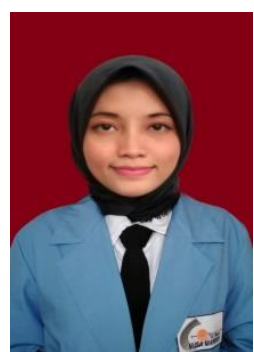

Mutia Lailatul Ilmi, A.Md.Kom. Jakarta 01 November 1998 dan tanggal lahir. Mahasiswi Universitas Nusa Mandiri Jakarta yang merupakan lulusan Ahli Madya Komputer dari Program Studi Sistem Informasi Universitas Bina Sarana Informatika Jakarta.

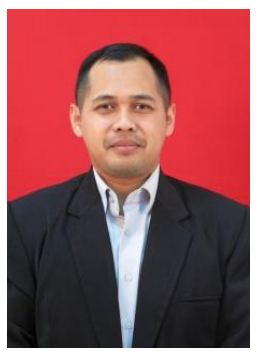

Joko Dwi Mulyanto, M.Kom. Banyumas, 1 Oktober 1990. Lulus pasca sarjana Stmik Nusa Mandiri 2016. Mengajar di Universitas Nusa Mandiri Prodi Sistem Informasi 